Book chapter in: Social Work Education in the Asian Pacific Region: Issues and Debates

\title{
Walking the Talk in Social Work Education
}

Ksenija Napan

Unitec, New Zealand

\section{Abstract}

This chapter focuses on the benefits and challenges of utilising social work values and principles when teaching, researching, evaluating and improving social work education. These values and principles are explored through their application within the social practice degree programmes at Unitec, New Zealand. A range of alternative and novel teaching and assessment methods are examined and evaluated in the light of their relevance and compatibility with social work education. Special focus is placed on, group assignments, creative individual assignments, field trips, experiential learning, self and peer reflection, inquiry learning, the use of individualised learning contracts and their relevance in 'walking the talk' in social work education. In an attempt to 'walk the talk' this chapter is organized in similar stages to the way in which social work education is organized in Aotearoa New Zealand and it integrates personal, professional and political discourses relevant for the co-creation of competent social workers.

\section{(in Croatian)}

Ovo poglavlje je usmjereno na dobrobiti i izazove pri korištenju vrijednosti i principa socijalnog rada u poučavanju, istraživanju, evaluiranju i unaprijeđivanju edukacije socijalnih radnika. Te vrijednosti i principi su istraženi kroz njihovu primjenu u dodiplomskim i poslijediplomskim edukativnim programima na Unitecu na Novom Zelandu. Alternativne i 
nove metode edukacije i procjene su istražene i evaluirane u relaciji sa njihovom kompatibilnošću s principima, vrijednostima i praksom socijalnog rada. Specijalna pažnja je posvećena grupnim zadacima, kreativnim individualnim zadacima, edukativnim izletima, iskustvenom učenju, samoprocjeni i kolegijalnoj procjeni, učenju propitkivanjem, idividualiziranim ugovorima namijenjenim učenju i procjeni koliko su te metode relevantne za edukaciju socijalnih radnika. U najmeri da autorica ostane vjerna primjeni principa socijalnog rada u edukaciji, ovo poglavlje je organizirano na isti način na koji je edukacija socijalnih radnika organizirana na Novom Zelandu te integrira osobne, profesionalne i političke diskurse relevantne za ko-kreaciju kompetentnih socijalnih radnika.

Key words: partnership, collaboration, inquiry learning, social work values and principles

Author's bio: Ksenija Napan, born in Croatia, moved to New Zealand in 1995, completed her $\mathrm{PhD}$ in social work education at Massey University, passionately involved in innovative teaching/learning practices in social work. Currently employed as an Associate Professor at Unitec, Faculty of Social and Health Sciences, Department of Social Practice where she engages in teaching in Masters and Bachelor courses, inventing and researching effective teaching/learning methods and supervision. Special interests: co-operative inquiry, spirituality and social work, transdiciplinarity, sustainability, action research, transcultural social work and creative social practice.

Personal statement: I believe in the transformative nature of social work education. When students experience empowerment that quality education brings, it is more likely that they will contribute to the transformation of social services and development of collaborative 
practices with their clients bringing forth personal, professional and political changes in the world.

\title{
Selection - Welcome to the Profession \\ Positioning the author
}

\begin{abstract}
All of science is nothing more than the refinement of everyday thinking
\end{abstract}

Albert Einstein

I have joined the academic establishment because of my dissatisfaction with the way I was taught social work and my insatiable desire to change the way it was done. My Bachelor of Social Work at University of Zagreb was a five year full time degree which included four years of course work and one year for a research thesis. The programme was mainly theoretical and encompassed five courses on various aspects of psychology and a number of social policy, economics and law papers. Only seven out of thirty-six papers were directly related to social work and these were mainly taught by academics with no practical social work experience. When I completed my five years of academic study, I became aware of my mind being overloaded with theories as well as of my ignorance and lack of skills for working with people to create any kind of meaningful change. To compensate for this I enrolled in every possible counselling and psychotherapy course that was offered, believing that more learning will help me to be effective in my future profession. I was aware that the ability to relate to my future clients and to the systems they operate in was essential. Although nobody told me during my academic training that social workers in Croatia were supposed to maintain the status quo and keep the disempowered masses under control, during my first fieldwork placement I started developing a hunch that that was the case. For five years, we as students regurgitated books on radical social work, action research, ecological systems theory and we started believing that we could change the world by merely applying these theories. It was only through 
my fieldwork placement that I discovered that only academics had the privilege of 'playing with ideas' and social workers were far too busy filling forms and finding loopholes to place the 'old Theresa in the old people's home before she burned herself and her 25 cats in her basement flat'. Some of my colleagues - practitioners did their best to forget everything they had learnt at university and adjusted to mediocre practice being careful not to rock the boat before they retired as old, worn out, disillusioned and 'fried' social workers. However, some followed their passion for social justice and 'managed to manage un-manageable' by engaging in creative social work practices, which significantly improved the quality of life of people whose lives have been damaged by war, injustices or their status in the society.

My aim at the time was to learn how to help my future clients to figure out better ways of living rather than being dependent on social worker's good will. I believed that the main task of an effective social worker is to make her/himself redundant. I hoped that my wide general knowledge, political awareness of the pitfalls of socialism as well as un-sustainability of capitalism would make me open to alternative views and enable me to envisage better ways of collaborating in a way that would bring forth the world. I wanted to work 'hands on' and I wanted to change systems, practices and realities that surrounded me, but before I had even put together my curriculum vitae to start looking for a job as a social worker I got offered a position at the university where I studied. I was quite surprised with this offer, because I was an inquisitive radical student, critiquing university practices and continuously suggesting ideas that could have been interpreted as outrageous. I was also aware, that in spite of being full of creative ideas, I was very far from being competent in teaching social work just after graduating. I was the one who always asked challenging questions, trying to make links with practice. I had hair dyed in three colours and a dog who sat in on all my lectures with me. It still puzzles me that in a traditional academic setting with so many rules, regulations and boundaries, they allowed me to get away with it and even 
gave me a student of the year award twice! Nevertheless, they did, and on top of that, they offered me a job! Then I realized that part of the reason was that I was probably the only 'mad enthusiast' who would accept the offer. The salary was ridiculously low but it included Masters tuition in the programme of my choice.

I chose the Masters of Social Psychiatry as it was a high quality radical, transdisiplinary programme. During my Masters I truly engaged with my learning and it provided me with a sound theoretical base that I could rely on when practicing my newly gained counseling skills. The joy of being treated like a colleague, being allowed to dialogue with my teachers, challenge them and expand my knowledge renewed my passion to transform social work education by making it more engaging, more practical and more integrated. Most of the professors in that Master programme were practitioners and that made a huge difference in terms of the integration of theory and practice. My dream of working in practice and transforming Croatian social work evolved into transforming social work education in order to transform social practices in a widest possible sense.

When accepting a job I was able to make it conditional upon continuing my engagement with practice, so I continued working for a local Centre for Social Work working with children and youth at risk in their own homes. I would work with two or three teenagers at a time. At the same time, a group of us started a support centre for youth and after a considerable success, we were invited to work at schools using drama and various experiential methods to keep teenagers out of trouble. Shortly after that, I started a part time counseling private practice. I learnt through experience how useful it is to visit people in their own contexts and I became the first Croatian travelling counselor, attracting a number of agoraphobic, elderly and physically disabled clients who were delighted to host me in their homes. Through these interactions, I developed an 
interest for the field of special needs and issues of equality and social justice.

My University job allowed me a lot of freedom although now, with hindsight I wonder how I managed to do all that at once. I have to say that my main calling was transformation and innovation. I was doing it and living it and it was more than a full time job. I was also combining a lot of work - my University work was informed by my practice and my practice was often part of some innovative action research project. While I was still studying, I would spend my summer holidays in the USA working in camps for adults and children with special needs. When I got a job at the University, during the first summer break I started the first Croatian holiday camp for persons with special needs and involved students in the organization and delivery of this service. For some persons with special needs this was their first holiday away from home or from the institutions they lived in and for some students this was their first encounter with people with special needs.

After that first summer camp students and clients were buzzing with motivation and I was encouraged by their families, and their social workers to include clients in a compulsory first year course Social work with Individuals. The role of clients was to act as experts in managing social workers and help our students become better practitioners. In return, students were supposed to support clients the way clients wanted to be supported. Clients were persons with chronic mental illness, multiple sclerosis, elderly people in nursing homes and persons with various special needs. Clients and students would meet during a whole academic year once a week for two hours and at the beginning would create a contract for their engagement which was a living and changeable document. Students would attend group supervision sessions once a fortnight with their client's social worker. Students would also attend two hours of theoretical lectures per week as well as two hours of collaborative 
practical work with fellow classmates where they would practice problem solving with one another in a peer to peer fashion, addressing either personal issues or problems that occurred during encounters with clients. Because of its intensive and challenging nature the method was named a Contact- Challenge Method (Napan, 1997).

I have spent seven years teaching at the University of Zagreb doing my best to transform the social work programme into one that would 'walk the social work talk'. It was not easy to do that, being the youngest staff member, but with time and persistence the Contact-Challenge method of teaching and learning social work practice came to replace the traditional first year placement. Croatian clients wholeheartedly accepted the offer and they have been helping to educate social workers in Croatia since 1990 (Napan, 1995, Urbanc, 2003).

When I moved to Aotearoa, New Zealand, I contextualized, applied and tested the Contact Challenge Method with a small group of Masters of Social Work (applied) students at Massey University, who had no previous experience in social work practice. The essence of the method is in its integrative nature; theory, practice and experience are integrated through personal, professional and political discourses, which enable students to become reflective practitioners. The Contact Challenge Method is not directly transferable to different contexts, but it is easily modifiable and contextualized within any educational programme.

Although I am not directly involved in applying the Contact Challenge method at the moment, the basic values and principles that permeate it, inform my teaching. These principles are; partnership, collaboration, mutual respect, reverence for all life, inspiration, purpose and joy in lifelong learning. These seven principles will be explored in the text that follows. 


\section{Selecting students for Bachelor of Social Work programmes}

Strange is our situation here on earth. Each of us comes for a short visit, not knowing why, yet sometimes seeming to a divine purpose.

Albert Einstein

Can we apply the seven principles mentioned above when selecting students who wish to enter our programme?

If we can, how do we enact them through our selection processes?

When selecting, what do we assess - a potential to learn, motivation, prior knowledge, skills, values, attitudes ....?

These are the questions that often get debated in academic departments. Attitudes range from a view that everyone should be given the opportunity to study to a carefully developed processes of selection to retain only 'fit and proper' students. Social work training has been a magnet for people who have been abused or marginalized in their life (Black, Jefferies and Hatley, 1993; Barter, 1997; Hanna, 2008). Assessing when the trauma experienced will contribute to effectiveness in practice or when it will hinder professional reliability is challenging and puts social work educators in a position of being gatekeepers for the profession. In an environment when education is often perceived as a business and when the income needed from student fees is essential for financial sustainability of the programme, the process of selection may become guided by different values and principles than providing a competent contingent of social work graduates.

Regardless of the political and financial context within which we operate, some of the key characteristics necessary for students to succeed in becoming effective social workers are: literacy, ability to learn, motivation to become a social worker, ability to listen, hear and follow simple instructions, ability to co-operate, critically reflect and be flexible, ability 
to act locally and see a bigger picture and resilience. Devising ethical and accurate processes to test if these characteristics are present in our applicants before enrolment becomes essential for effective selection in social work programmes. A process that worked well for us at Unitec was as follows:

- having a paper selection first when students submit their application with a brief outline of their motivation to study.

Providing all requirements for studying at a tertiary level are satisfied, students are invited for a selection day where they are put in groups and invited to participate in a range of activities. These activities are usually some variation of the following:

- a short essay written on the spot, usually related to Te Tiriti O Waitangi (a founding document for New Zealand) and biculturalism

- a group activity which tests for prejudices and explores values and ability to co-operate as students need to reach a consensus about an ethical issue in small groups

- drawing a timeline which allows prospective students to briefly reflect on their life up to the day of their enrolment to our programme

- a group activity which tests for the ability to listen and introduce their fellow applicant respectfully followed by sharing a situation when they demonstrated resilience

These group activities are accompanied by individual brief interviews with two culturally different staff members. All these processes are collaborative and involving, meaning that students have a chance to interview staff as well. Former and present students are available to talk about the programme with prospective students and answer questions they might have. 
A quality of the selection process is closely related to retention and quality of our graduates. I strongly advocate the position that either we need to have a thorough selection process or an open entry with very rigorous assessment in the first year. Social workers deal with the most vulnerable people in our society and one incompetent social worker is one too many. The selection process described above is guided by principles set out earlier:

- partnership - through reflection on Te Tiriti O Waitangi, dialogue with students, sharing how we work and by giving students a taste of activities they will be engaged in during their studies

- collaboration - through group activities where students need to demonstrate the ability to work together

- mutual respect - through respectfully introducing one another and exploring values in context through a metaphorical story

- reverence for all life - through sharing stories of resilience

- inspiration - through sharing their motivation and interest for social work and at the same time staff members presenting their interests and passion for the profession

- purpose - through drawing a time line and seeing what brings them to social work and how it fits with their past experiences and future aspirations

- joy in lifelong learning - through relaxed and friendly atmosphere where students (current, past and future) and staff exchange ideas about lifelong learning as most of our applicants are mature students with a wealth of life experiences

Although, the process is carefully planned and organized, to prospective students it appears to be lighthearted and quite enjoyable. Students generally complete a selection day feeling engaged, informed and enthused about the journey they are embarking on. Through group interactions with students, all staff have a chance to see all students in various situations and that gives them a larger picture of their values, skills and abilities to 
become competent social workers. All staff simply assess each student as a 'yes', 'no' or 'maybe', and only the ones who receive 'no' or 'maybe' get discussed. We aim for a consensus in finalizing our decision for accepting students to the course.

\section{The First Year - Developing Respectful and Collaborative Partnerships}

No one wants advice, only collaboration.

John Steinback

In its essence, social work is based on collaboration. Practising collaboration while studying will increase students' ability to form collaborative and respectful partnerships with their clients. Social work clients, especially the ones who have spent a lot of time interacting with social workers hold a lot of practical wisdom in the sense of 'managing' or 'coping with' social workers as well as the insider's knowledge of their situation and their strengths and abilities. In a climate where social workers are perceived either as 'rottweillers' taking away people's children or 'do gooders' who preserve the status quo, the notion of collaborative practice becomes essential.

This is closely related to principles of human rights and dignity as well as the principle of social justice as outlined in Aotearoa New Zealand Association of Social Workers Code of Ethics (2008). True and equal partnership presumes self-determination, responsibility for one's actions, belief in people's resilience and strengths (Saleeby, 1997) and the ability to make choices even in environments where choices are very limited (Glasser, 1999). Respect presupposes trust but not blind faith; it includes a co-creative process in relating to other people where both participants engage in a dialogue with interest and curiosity, with the aim to improve the quality of life. Meaning that, when a social worker and a client 
discover a better way of managing life or when a teacher or a student make new links between their theory and practice, both of their lives get transformed. This is true partnership. We meet and through a trusting dialogue, we co-create a new reality abundant with new possibilities. Preferably, clients and students will experience more of these moments than social workers and teachers, however, if we believe in the idea of lifelong learning - this is exactly where and how bringing forth the world becomes reality.

For academics, this means the development of an art of teaching in a way that the body of knowledge gets enriched during this process - and not diminished or distorted. For a social worker, this means figuring out a new way of reaching a client while developing empowering contexts. A cocreative dialogue is the process that facilitates this. I use a lot of dialogical teaching, even in large classes of 70 or more, even when that may mean initially talking with $10 \%$ of the class and most of the other students listening. Eventually almost all come on board and release their inhibitions when they feel respected and appreciated. I learn their names (and expect from them to know how to pronounce mine), I show interest in them, I make a conscious intention to see their strengths and abilities, especially when these are not very visible.

I also challenge my students to bring out the best in them, hoping that this will make it easier for them to challenge me when needed, bearing in mind all cultural and contextual issues that may prevent them from doing so. I tend to live the idea of us being collaborators in the process of learning social work and pussyfooting around each other, pretending by being nice but not honest will not help us get there. My aim is to role model cooperation and partnership hoping that my students will be able to transfer and build on these principles in their social work practice, homes and communities. 


\section{Practical teaching tools used to engender collaboration}

- learning contracts (Knowles, at al, 1998; Anderson, 1996),

- students choosing the format of their assignments - to reflect their learning style, culture, utilisation of prior knowledge and existing wisdom in the classroom and ensuring that learning outcomes get covered or expanded

- focus on special abilities, strengths and prior knowledge

- encouraging students to do group assignments, rewarding collaboration

- teaching collaboratively

- encouraging low contributors to participate and supporting high contributors to develop listening skills and reflection

- encouraging or requiring peer-reflection

- encouraging dialogue and agreeing to disagree

- developing respectful curiosity in difference and uniqueness

The notion of biculturalism is so essential for New Zealand, relevant for all countries and closely linked to the principle of partnership. In my context, it manifests through:

- acknowledging Maori as Tangata Whenua (people of the land) of this country,

- practising respect within a bi-cultural political context,

- learning about humbleness and appreciation of unity in diversity,

- developing a respectful curiosity for indigenous knowledge,

- development of confidence in cultural identities by knowing and understanding influences of origins and family backgrounds.

Respect and appreciation of client's resilience and knowledge is a prerequisite for true collaboration in situations of unequal positional power. Learning and experiencing the effectiveness of indigenous models helps students develop respect and interest in practices outside of their comfort zone. 


\section{Practical teaching tools used to accomplish the principle of bicultural partnership}

- employing competent Maori practitioners to be inspiring role models for our students and to share their knowledge and experience

- inviting exciting Maori guest speakers, encouraging students to submit assignments in Te Reo (Maori language)

- exploring Maori practices in class with students, encouraging Maori students to participate

- organising Noho Marae where students stay for 3-4 days on a Marae to learn Maori protocol and experience collectively cultural practices

- comparing and contrasting Maori practices to other indigenous models of practice as well as western concepts and effects they may have on clients, their families and communities

- promoting inquiry learning through development of genuine curiosity in various ways of perceiving reality

- exploring belief systems and how they shape practices and modelling by teaching in partnership with Maori lecturers

The first year is essential for students to discover if they really want to become social workers. The more we as a faculty invest in them in this first year, the easier will be for them to continue their studies with integrity and motivation. Unfortunately, the first year happens in the largest classes, creates most stress on students' families and students are often unaware of supports available on campus or too busy organising their changed lives to use them effectively. The major task for educators is to perceive abilities and potential in first year students, encourage them to experiment and explore a number of areas of practice (theoretically and practically) and to create a context with clear and transparent boundaries 
where students can grow safely and confidently. The balance of challenge and support is essential and it is a way of showing respect.

Social work practice and social work education are permeated with issues of social control. Clarity and transparency are essential when we do not want clear boundaries to be experienced as tools of social control.

Explaining the purpose for rules and regulations within a programme as well as linking them with issues related to social work practice make this learning relevant, meaningful and contextualised. In this context, every conflict or disagreement becomes a welcomed learning opportunity. Social work principles can guide social work teachers when faced with challenging situations in the classroom.

\section{Middle years - heart of the programme}

Kaua e whakaarohia te mahinga engari te otinga (Think not on the labour, rather reflect on the completion)

\section{Maori proverb}

'During its history, social work has developed a dual focus. Firstly, to enable and empower individual families, groups and communities to find their own solutions to the issues and problems that beset them. Secondly to learn from specific instances of need, to inform society at large about the injustices in its midst, and to engage in action to change the structures of society that create and perpetuate injustice' (ANZASW Code of Ethics, 2008, p 4).

Socially just social workers do not serve merely as tools of social control. For the effective pursuit of social justice, one has to have a sense of purpose in their work and to consider the impact they have on their clients, their families and communities. This sense develops through the ability to critically reflect on wider contexts where an individual social worker aims to practice and by exploring what attracts them to that particular area of practice. Ageless questions like: 


\section{Who am I?}

\section{Where I am coming from?}

Where am I going?

\section{How can I contribute?}

address issues of purpose.

Reverence for life (Clark, 2006, Manton, 1955) is the core of all professions that attempt to bring forth the world. Reverence relates to respect with love and as such, it embeds love as a life force. Love transcends justice as Barnes (1994) noted, hence it includes justice and to do so it has to satisfy justice. Social justice without love lacks awareness of importance of the relationships and love without the sense of social justice can justify cruelty or become sentimental. Both love and justice need wisdom and reverence for their application in social work practice. Dialogues about issues related to love and justice become essential for the development of effective social workers. As beliefs shape actions, attention to students' beliefs through reflexive exercises will crystallize their intentions and therefore make them more accountable for their actions.

Recruiting exceptional fieldwork co-ordinators and fieldwork supervisors significantly influences the quality of learning. Unfortunately, they are a rare find. Fieldwork co-ordination is too often seen as a 'poor little sister' of academic teaching and this is reflected in the separation of that role from the academic teaching, less qualifications required for the role and minimal acknowledgment of practitioners who are field work supervisors and often volunteer their time to educate our students. The job of placing students becomes a difficult task and because of that, less than appropriate placements are accepted which often results in students' dissatisfaction due to the impossibility of achieving numerous learning outcomes that need to be covered in a placement portfolio. 
At this stage, students begin to integrate their values, beliefs, personal experience and prior knowledge with information and skills gained during studies. Critical thinking is developing and prejudicial values and beliefs are challenged. Peer support and time for reflection and discussion become essential during this early formation of a professional identity.

Experiential learning, inquiry learning and whole people learning methods (Kolb, 1984, Heron, 1996) promote inquisitive, exploratory, empowering and appreciative ways of being that attend to students in the totality of their experience and the context they are immersed in. These methods tend to integrate personal, professional and political elements as well as theory, practice and personal experience and require skillful facilitation.

Practical teaching tools used to engender purpose, reverence, inspiration, joy in lifelong learning, awareness of social justice and development of skills, values, beliefs and knowledge necessary for effective social working

- dialogues with students on current topics,

- debating issues of concern

- practising justice focused teaching and learning and developing clear boundaries and rules of engagement

- developing learning contexts where mistakes are welcomed as learning opportunities

- elimination of fear from judgement

- required readings and critical reflection

- providing time and space for students to explore personal issues that may enhance or hinder their future practice

- reflective journals

- encouraging inquiry learning

- field trips to various seminars, festivals and community events

- role plays and skills training

- students working with one another on issues of concern

- exploration of ethical issues and critical debates in social work

- court visits

- time for deep reflection and critical analysis 
- creative assignments using various methods to cover common learning outcomes

- assessments having a strong learning component and related to social work practice

- exploration of how beliefs shape professional practice

- personalised learning contracts and

- self and peer reflection.

This is not a definitive list, it is here just as an inspiration to engender and initiate a range of alternative methods to keep this part of education relevant, exciting and alive.

\section{The final year - integration - social justice and empowerment in action}

Never doubt that a small group of thoughtful, committed citizens can change the world. Indeed, it is the only thing that ever has.

\section{Margaret Mead}

The final year of the programme consolidates knowledge, skills, values and attitudes and it shapes the professional identity of a budding social worker. Longer fieldwork placement in the final year usually secures jobs for many of our graduates, but also makes some of them aware of the fields of practice they do not want to engage with when they graduate. Reflection on theories learnt and skills gained during the course becomes a platform for examination of values and beliefs, which will guide their practice. Inquiry learning (Heron,1996a, Napan, 2009) becomes more and more relevant. Students become more self-directed and focused on areas of their interest. Some become aware of how little they know and how vast is the area of practice they are embarking on. Comparing and contrasting various theories, models and principles as well as finding one's favourite theories or orientations characterise this stage while competent students report most joy in learning. Allowing time for self-reflection provides space to revisit some life decisions and the last year is crucial for the development of purpose for students' future direction. This sense of purpose will keep them grounded when realities around them are 
fragmented, it will enhance their creativity when clients appear to be stuck and will give them a sense of contributing meaningfully in a world which through a social worker's practice may not look very bright.

The Just Practice paper within a Bachelor of Social Practice programme at Unitec was developed to invite and inspire the graduating class to incorporate social justice concerns into their social practice. They were invited to define their social justice intentions, purposes, aims and contexts for their practices in light of the retrospective accounts of those who have gone before them and have been acknowledged for their own 'just practice'. This was made possible by providing opportunities to bring the graduating class into close acquaintanceship with the 'lore' of just practitioners (Epston, Rennie, Napan, 2008). This course invites students, after being inspired by individual visits by just practitioners (many of whom are at the end of their careers), to co-create in small groups a virtual just practice agency that would operate according to particular group's idea of what social justice entails. The focus on creativity and possible or seemingly impossible ventures enables students to envisage and develop a focus for their future just practice.

During the last year of their studies at Unitec students undertake a group research project (Bridgman, 2008) where they inquire and apply a methodology of their choice to the topic of their interest. It is a bona fide research project, which needs to be approved by the Unitec ethics committee and gets presented to the class. In this final year, principles of collaboration, partnership, mutual respect, reverence for all life, inspiration, purpose and joy in lifelong learning are put to the test. Working in groups under stress with deadlines and family obligations forces students to develop exceptional organising skills and good time management, so relevant for their future practice. 
Another example of utilising these principles in teaching was in an elective paper called Creative Social Practice that was conducted as an Academic Co-creative Inquiry in 2008. This meant that students and myself, as a teacher, co-created the course structure, processes, content and the assessment process. Learning outcomes proposed by the course outline were personalised and modified in the light of students' interests and learning needs. Students agreed to do a presentation and a written assignment as a way of covering learning outcomes. To my surprise, students insisted for their written work to be assessed by me and not do written self and peer reflection, however as most of them produced a high quality assignments, it was obvious that a lot of self-reflection happened before submitting. They also wanted their presentations to be peer assessed, but only verbally just after presenting, and agreed that peers' feedback contributes to their final mark, but the actual grade should be assigned me. They refused to give marks to one another saying that assigning marks destroys relationships. On the other hand, receiving a mark from me was seen as manageable as it was my job to do that. This collaborative venture unleashed students' creativity and sense of ownership of the course. Some brought in some exciting guest speakers, some elaborated on interesting integrations of their hobbies, interests and passions into their social work practice. Some produced individual assignments, some formed groups and worked collaboratively. All marking criteria were mutually agreed on and learning outcomes proposed by the course outline were covered. Most emphasised a sense of privilege while being able to dialogue about advanced, creative practices and being grateful for space provided for reflection and development of focus for application of their creative ideas.

The main challenge of collaborative work is the assessment of group assignments and ways of forming student groups. Within a Bachelor of Social practice at Unitec, in some courses groups are self-selected, in some lecturers pre-organise them. The purpose of engaging students in doing 
group assignments is that when students are involved in tasks that cannot be attempted alone multiple skills are brought to bear on problems and conflicting views are aired and considered (Strauss and U, 2007; Gatfield, 1999; Young and Henquinet, 2000). Group assignments are also useful for developing skills for employability (Strauss and U, 2007). Skilful management of collaborative assessment is essential. When groups are teacher selected with no allowance for student initiated modification a rationale for this needs to be clearly explained at the beginning. For example, in the Just Practice course, students are purposefully put in groups that intentionally encompass students who major in different strands of the programme (Social work, Community Development and Counselling). The groups reflect cultural, age and gender diversity and students cannot negotiate group membership for the purpose of learning how to work interdisciplinary and with people with different backgrounds to their own. When this is explained to them, accompanied with the idea that this is a learning opportunity, they accept it and reflect on challenges they faced during the process in their assignments and take them as opportunities for learning.

\section{Practical teaching tools used to engender smooth transition to social work practice and development of a professional identity}

I find peer and self reflections extremely useful in teaching as a measure of performance and as a learning experience. These methods also allow students to explore areas of practice they feel attracted to, dare to get engaged in practices that are outside of their comfort zone, enhance their learning experience and build on their strengths. Furthermore, they mirror performance review processes in most social work agencies. During that process, providing a space and time for exploration of beliefs and attitudes that will guide their professional practice, as well as increasing understanding of political contexts that will influence it, becomes essential as students progress through the degree. As this form of advanced teaching is personalised, small trusting groups are more 
suitable, however, even in large groups quite a lot of interaction and deep learning is possible. Advanced and specific questions arise at this stage and conducting teaching in an inquiry mode benefits the development of curious and competent scholars and practitioners.

As much as on-line components of various courses contribute to the fruitful dialogue, a balance of face-to-face and on-line contributions needs to be attended to for a simple reason that most social work practice is still done face-to-face.

The integration of theory and practice and the transition from study to work can be facilitated by:

- linking assignments for theoretical courses to practical social work

- involving practitioners in teaching and assessment

- using stories from practice and inviting practitioners and clients to talk about their experiences

- encouraging inquiry learning

- creative assignments by student choice focusing on the field of practice where their interests lie

- supporting students to transcend artificial divisions between theory and practice

- presenting social work theories in a very practical manner

- continuously theorising and reflecting on practice

I have been experimenting with alternative, creative assignments for years. Students choose what kind of assignment they want to submit and outline in their learning contracts how are they going to cover the required learning outcomes. They are encouraged to think outside of the square and many use various art forms of expression. This is often accompanied with peer and self reflections that are well structured, in a written form and focussed on coverage of learning outcomes. The amount of time students 
put into these assignments is considerable as well as their feedback on how much they have learned while painting, making a movie, song, poem or performance while still focusing on learning outcomes related to social work.

However, the process of self and peer reflection is a challenging one. Students can do it for real and benefit from it by learning how to give a critical feedback respectfully that will prepare them for their future practice, but they can also choose to fake it - just to satisfy course requirements. We live in an environment where honest feedback can hurt, where external evaluation is perceived as more 'objective' than selfreflection. Exposing students to self and peer reflection, even though they may do it just to satisfy course requirements and not be open to receive it or honest while giving it, still creates a context where reflection is encouraged and the myth of perfection deconstructed.

This is beautifully outlined in this Bachelor of Social Practice graduate's quote:

I clearly remember my first paper and how I did not like one member of our group as she would not let me or the two other members have a say, so being the idiot I was I let it go and just backed off, but swore to myself I would never work with her again. Now two years down the track and with a lot more confidence in my own abilities I have no problems with group work, because as a group we delegate responsibilities and everyone does their bit and if they don't, myself and other members of the group do not hesitate to speak out. Not in a nasty way but we all make it clear that we must work equally or we will do something about it. I have never had a repeat of the problem I had in my first paper in January 2005.

(Unitec BSocP Graduate, 2008)

\section{Instead of conclusion - reflection}

By three methods we may learn wisdom: First, by reflection, which is noblest: second by imitation, which is easiest; and third by experience, which is the bitterest. 


\section{Confucius}

The main purpose of this chapter was to inspire the reader to experiment with creative methods of teaching and learning social work, explore the possible ways of integrating social work principles and values in teaching and making almost every experience a learning experience. Challenges of group, self and peer reflection have been explored and their relevance for social work practice considered. Principles of partnership, collaboration, mutual respect, reverence for all life, inspiration, purpose and joy in lifelong learning can easily provide a meaningful context for all learning outcomes that need to be covered in a range of social work courses. Time for reflection and dialogue as well as time for experimenting with new ideas encourages development of lifelong learners and politically aware social workers who are able to see globally and act locally with integrity and competence.

All these principles are interrelated and the presence of one is embedded in others. Learning in social work never stops and practitioners either go towards specialisation in one area of practice or towards transdisciplinarity by expanding their horizons and by making meaningful links and connections with other professional areas while still staying accountable to their primary discipline.

I believe that the future of social work education is in "high touch-high tech', integrative, whole people learning where personal, professional and political aspects are addressed. I believe that social work education needs to be informed by social work practice, the latest findings in educational research and guided by social work values and principles. It also needs to be contextualised and continuously improved according to the feedback from all stakeholders including practitioners, clients, students and researchers. Walking the talk in social work education by practising what 
we teach appears to be a relevant way of engaging students and creating meaningful links between personal, professional and political realities.

\section{References:}

Aotaroa New Zealand Association of Social Workers. (2008) Code of Ethics. ANZASW National Office, Christchurch, New Zealand.

Anderson, G. (1996) Learning Contracts. A Practical Guide. Stylus Publishing, Inc. 22883 Quicksilver Dr., Sterling, VA.

Barnes, G. (1994) Justice, Love and Wisdom - Linking Psychotherapy to Second-Order Cybernetics, Medicinska Naklada, Zagreb.

Barter, S. (1997) 'Social Work students with personal experience of sexual abuse: Implications for diploma in social work programme providers'. Social Work Education 16, (2), pp 113-132.

Black, P., Jefferies, D. \& Hatley K. (1993) 'Personal History of Psycho social trauma in the early life of social work and business students', Social Work Education, 29 (2), pp 171-180.

Bridgman, G. (2008) Presentation to Undergraduate Board of Studies meeting, Unitec, October 2008.

Clark, G. (2006) The man who tapped the secrets of the Universe, The University of science and philosophy, Kessinger Publishing,USA.

Epston, D., Rennie, G. Napan, K. (2008) 'On becoming a Just Practictioner: Experimenting with the final paper of an undergraduate programme as a rite of passage', in Epston, D. Down Under and Up over travels with Narrative Therapy, AFT Publishing Warrington England, pp 81-95.

Gatfield, T. (1999) 'Examining student satisfaction with group projects and peer-assessment'. Assessment \& Evaluation in Higher Education, 2, 365-377.

Glasser, W. (1999) Choice Theory: A New Psychology of Personal Freedom, HarperPerennial, London.

Hanna, S. (2008) 'Not so strange - an application of attachment theory and feminist psychology to social work supervision'. Aotearoa New Zealand Social Work Review, Vol. XIX-3, Spring, pp 12-22. 
Heron, J (1996) 'Helping Whole People Learn' in Boud, D. and Miller, N. (Eds) Working with Experience: Animating Learning, Routledge, New York.

Heron, J. (1996a) Co-Operative Inquiry: Research Into the Human Condition, SAGE Publications, London.

Knowles, MS., Holton, E.F., Swanson, RA (1998) The Adult Learner: The Definitive Classic in Adult Education and Human Resource Development. Butterworth- Heinemann, USA.

Kolb, DA (1984) Experiential Learning: Experience as the Source of Learning and Development, Prentice-Hall, New Jersey.

Napan, K. (1995) 'Experiential Learning - What is a Contact-Challenge Method?' Skolske Novine, May, 1995. Zagreb, Croatia.

Napan, K. (1997) 'The Contact-Challenge Method in Search of Effective Teaching and Learning Social Work Practice', Aotearoa New Zealand Social Work Review, March/June 1997. Vol IX, No. 1\&2. New Zealand Association of Social Workers.

Napan, K. (2009) Academic Co-creative Inquiry: Creating Inclusive Processes for Learning, Refereed proceedings from Educational Integrity Conference, University of Wollongong, 28 - 30.9. 2009.

Saleeby, D. (1997) (ed.) The Strengths Perspective in Social Work Practice (2nd Ed) Longman, New York.

Strauss, P. and U, A. (2007) 'Group assessments: dilemmas facing lecturers in multicultural tertiary classrooms', Higher Education Research and Development, Volume 26, Issue 2, June 2007, pages $147-161$.

Manton, Jo (1955) The Story of Albert Schweitzer, Methuen \& Co Ltd, London.

Urbanc, K. (2003) 'The importance of field-instruction for the development of social workers' professional identity'. Ljetopis Studijskog Centra Socijalnog Rada, University of Zagreb, 10(1), pp.61-69.

Young, C. B. and \& Henquinet J.A. (2000) 'A conceptual framework for designing group projects'. Journal of Education for Business, 76(1), 56-60. 